\title{
Edible wild plant use in the Faroe Islands and Iceland
}

\author{
Ingvar Svanberg ${ }^{1 *}$, Sigurður Æggisson ${ }^{2}$ \\ ${ }^{1}$ Uppsala Centre for Russian and Eurasian Studies, Uppsala University, Box 514, 75120 Uppsala, Sweden \\ ${ }^{2}$ Hvanneyrarbraut 45, 580 Siglufjörður, Iceland
}

\begin{abstract}
This paper reviews the use of wild edible plants in the Faroe Islands and Iceland from the times of the first settlement of Norse people in the Viking age until today, with a special emphasis on the 18th, 19th and 20th centuries. Animal products have been an important source of nutrients for the islanders of northern Atlantic. Cultivation of cereals on the other hand has played a minor role, and had already been abandoned by late medieval times in Iceland and by the early 20th century on the Faroes. Crops such as potatoes, turnips and other roots were only grown in the small patches of cultivated soil. Wild plants have therefore been of some importance for the Faroese people and the Icelanders; in the last centuries especially for the rural poor and during times of recessions. The native Angelica archangelica L. was gathered in the wild and also cultivated in gardens for centuries. A few species have been part of the regular food staple. Some plants are still gathered and made into food products by small companies, especially in Iceland. In the Faroes, the economic aspect of edible wild plant taxa is mostly of historical interest, although a few products of $A$. archangelica are sometimes available. Two taxa have been exploited as regular food exclusively in Iceland: Cetraria islandica (L.) Arch. and Elymus arenarius L. Icelanders have used C. islandica from the early settlement days and continue to do so today, E. arenarius became obsolete as a food plant a century ago.
\end{abstract}

Keywords: wild food plants, algae, lichens

\section{Introduction}

Tapping little known traditions of local plant knowledge in rural areas is an important issue for contemporary ethnobiology. The traditional use of wild "plants" (vascular plants, fungi, algae, lichens) for food is a popular biocultural domain to research [1]. However, despite many field works and increasing interest in archival sources many areas of Eurasia still remain blank spots on the ethnobiological map. Marginal regions in the North belong to these little researched areas [2].

The populations of the Faroe Islands and Iceland share a common cultural heritage as descendants of the Norse Vikings that settled between the 9th and 10th centuries in these far-away places. Faroese people and Icelanders used the gifts of nature from the beginning, both for food and as remedies against illnesses, although most of what can be said about the earliest period despite a few archaeobotanical studies, is guesswork. From early medieval times we have information in the Eddas, the Icelandic sagas and the law literature [3].

\footnotetext{
*Corresponding author. Email: ingvar.svanberg@ucrs.uu.se

This is an Open Access digital version of the article distributed under the terms of the Creative Commons Attribution 3.0 License (creativecommons.org/licenses/by/3.0/), which permits redistribution, commercial and non-commercial, provided that the article is properly cited.
}

\section{Background and methods}

Iceland has a total area of $103000 \mathrm{~km}^{2}$ and a population of about 320000 (2012), which makes it the most sparsely populated country in Europe. From 1262 to 1918 Iceland was part of the Norwegian and later the Danish monarchies. Iceland became independent in 1918 and a republic was declared in 1944. Icelandic has been codified as a literature language since medieval times. Traditional food culture was based on marine mammals, seabirds (meat, eggs), fish, seashells, cattle, sheep, horses and dairy products. While animal husbandry and hunting have been of importance, agriculture was very limited. Some plants were gathered in the landscape, otherwise vegetables have been of very little importance [4-6].

The Faroes, located in the northeastern North Atlantic Ocean, constitutes a group of 17 populated (out of 18) islands with a total area of $1400 \mathrm{~km}^{2}$ and a population of nearly 50000 people (2012). The Faroe Islands are still under the sovereignty of Denmark, but have their own government. Faroese has been used as a colloquial language beside Danish until the last century, when it became a written language. Animal products did and still do dominate the traditional food culture. As in the case of Iceland, it is very much based on fish, seabirds, whale (especially Globicephala melas Traill), sheep, and to some extent domestic geese. Various bivalves, e.g. Mytilus edulis (L.), Modiolus modiolus (L.), and Ensis ensis (L.), have been eaten in some villages, especially during times of food shortage. Cereals and vegetables have played a minor role in the traditional cuisine, of which potatoes and other root vegetables have been the most common [7-10]. 


\section{Landscape and flora}

According to a 12th century source Iceland was "forested from mountain to sea shore". However, it was deforested due to overexploitation (fuel, construction material) and grazing. Animal husbandry was a major livelihood. Wide areas were used for grazing and scattered meadows were used for haymaking. Very small remnants of the former tree flora still exist. The landscape is part of the Arctic region and the vegetation consists mainly of grassland. Large areas are non-vegetated or only sparsely vegetated. There are 490 vascular plant taxa, 460 mosses, 700 lichens and 2100 fungi species growing wild in Iceland [11]. Approximately 30 wild taxa are reported as having been utilised as food. Faroe Islands are part of the Atlantic region and the Faroese people have access to over 400 vascular plant taxa, 350 mosses, 470 lichens and 600 species of fungi [12]. Only around 20 have been used as food.

Until the nineteenth century, the settlers mostly subsisted on shepherding, hunting and fishing. Wild plants have always played a small but nevertheless important role in the economy of the populations of Iceland and the Faroes. Seaweed has been harvested as fodder and manure, grass has been used to thatch the houses, and turf has played an important role as fuel. Some plants and especially lichens have been used for dying wool, while the grass and hay production was crucial for keeping sheep, horses and some cattle. Cultivation of crops has been of minor importance; mostly barley in small fields and more recently potatoes. The soil is used for the production of grass and to some extent potatoes, the latter an innovation adopted in the islands in the middle of the 19th century. The meadows with grass and many flower plants are harvested in the early fall for production of fodder. In the towns and villages, there are also gardens with some vegetables and ornamental flowers $[4,5,7,10,13]$.

\section{Sources for this review}

This review is based on archaeological, botanical, ethnographical and historical research, travelogues, ethnobotanical studies available, and on field research on the Faroes and Iceland [14-17]. The native scholars Eggert Ólafsson (17261768), Bjarni Pálsson (1719-1779) and Jens Christian Svabo (1746-1824) travelled, inspired by Carl Linnaeus travelogues, on behalf of the Danish authorities Iceland and Faroe Islands respectively, and gathered the best material on traditional plant use already in the 18 th century $[18,19]$. A review of local plants some of which had been used until very recently was published by the Faroese botanist Rasmus Rasmussen (1871-1962) in 1946 [20]. The reverend Björn Halldórsson (1724-1794) in Sauðlauksdalur compiled already in 1783 a commentary on Icelandic useful plants [21]. Icelandic ethnologist Lúðvík Kristjánsson (1911-2000) has put together a monumental work on gathering activities along the shores and in the sea of Icelandic coasts, including the exploitation of plants [22].

\section{Results}

Very few taxa have been used as food plants. Some of the plants eaten are the same as the peasantry in Norway and other parts of Scandinavia utilised for the same purpose. However, a few plants are unique for these regions [23]. The wild plants that have been used for food are presented according to the categories given by Turner et al. [24].

\section{Root vegetables}

Very few underground plant parts have been used in the Faroes and Iceland. The rhizomes of Angelica sylvestris L. were eaten in the Faroes in the 18th century and still in end of the 19th century [15,20]. Roots of Angelica archangelica L. were considered to be the most important part of the plant in Iceland, and "going mountain rooting" was the term applied to the gathering of this valuable source of nutrition [3]. From Iceland there are data available on the use of Bistorta vivipara (L.) S. F. Gray eaten raw or made into bread [18,21].

A couple of species were used both in the Faroes and in Iceland. The use of the nutritious roots of Potentilla anserina L., eaten boiled or roasted, is the most interesting [15,18,21]. It has been used as food also in other Norse-influenced areas of Shetland Isles, Scotland and Norway [25]. The small, rich in starch, nodules attached to rhizomes of Equisetum arvense L. have been eaten in the Faroes and Iceland. Since they are sweet-tasting the habit has survived among children until rather recently. The nodules were gathered in spring-time while tilling the soil $[26,27]$.

\section{Edible greens}

Ever since the first settlement of Iceland and the Faroese, wild growing Angelica archangelica L. has been used for human consumption and has also been important as medicinal herb. It was also eaten fresh, picked in the wild on the mountainsides. In Iceland all parts of the plant were used - the seeds, leaves, stalks and roots and were eaten fresh, fried or boiled (often in milk); or prepared in some other way [28].

The most commonly used green plant both on the Faroes and in Iceland was probably Rumex acetosa L. It was usually served with meat, fish or as a flavour to bird soup. It is still recommended in a cookbook as tasting well with boiled puffin $[15,29]$. Generally speaking, the common sorrel (Rumex acetosa) is the most popular wild food plant also in Iceland. It was used almost in the same way as in the Faroes $[18,21]$.

Lady's smock, Cardamine pratensis L., was used in soup in the Faroes. The use of Taraxacum sp. tender leaves as a spring vegetable is mentioned from the Faroes in 1800. The Faroese children still suck the sweet nectar from the flowers of Vicia cracca [15].

An interesting green plant is Cochlearia officinalis L. that was eaten against scurvy and to promote good health among herdsmen and fowlers. Its use is also recorded in historical sources from Shetland, the Faroe Islands and Iceland as well as northern Norway $[15,20,30]$. This use of the plant was already known in the Faroe Islands in the late 17th century and persisted until this century. Lucas Debes (1673) writes that God has blessed the Faroe Islands with this plant species, as well as with some other herbs like cress, veronica and sorrel; also remedies against scurvy. Scurvy grass was considered good for one's health and also gave strength and stamina thus preventing exhaustion, caused by a shortage of food [31]. In Iceland, it is probably first mentioned in the saga of Grettir the Strong (early 14th century); but as a precious food its story seems to begin in the 17 th century, in the island Grimsey off the northern coast. It was usually gathered from late August till the end of September if it was to be used as food for humans (also during winter if the ground was not covered by ice and snow). Scurvy grass was widely used to make soup and porridge and to eke out flour in bread making, as well as being eaten fresh as salad. The root was eaten raw or boiled. Some of these methods, mostly the last ones mentioned, are still in practice, here and there. 
The use of Oxyria digyna (L.) Hill. in the Faroes is only historical. Jens Christian Svabo describes in the 1780s how people flavoured flour gruel with alpine mountain sorrel to make the dish sour [19]. The same could almost be said about Iceland, where it is common all over. Nowadays people mostly consume the plant fresh to quench their thirst while on tour walking in the wilderness. It is also used in salads at home, or the leaves are boiled in water and the mixture drunk cold as refreshment. Others use it in various soups and porridges and in recipes instead of lemons. The seeds are sometimes used in bread-baking, although only on a small scale. In Iceland Honckenya peploides (L.) Ehrh., is fermented and in that state used as food, like sauerkraut. Oxalis acetosella L., Rumex longifolius DC., Stellaria media L., Chamerion latifolium (L.) Holub. and Epilobium angustifolium L. have also been used in soup or stews or consumed fresh as salad. Also Silene acaulis L. was gathered, boiled and eaten with butter $[18,21,22,32]$.

\section{Berries}

Due to sheep grazing, wild berries were (and are) scarce in the Faroese mountains and mostly eaten on the spot when found (Vaccinium myrtillus L.). The only one yielding some harvest is the Empetrum hermaphroditum Hagerup, picked and usually eaten on the spot. Berries of Cornus suecica L. were eaten by children and youth in the Faroes $[15,19,20]$.

The Icelandic people have doubtless used wild berries, including the crowberry, Empetrum nigrum L. and Empetrum hermaphroditum Hagerup, in food since the time of settlement although other berries, such as bog bilberry, Vaccinium uliginosum L., and bilberry, Vaccinium myrtillus L., were generally considered better. According to the law of the Icelandic Commonwealth, it was permissible to eat berries on other people's land, but those attempting to gather them and take them away could be penalised. Berry fields were recorded as fringe benefits in many old farm registers. Crowberry wine was made at Skálholt in early centuries, possibly because of a lack of access to foreign communion wine $[4,18]$.

In more recent times the most usual way to eat fresh crowberries has become an accompaniment to the Icelandic skyr (curdle milk), soups, puddings or the mixture of skyr and porridge known as "hræringur". A good way to preserve vitamin C in a land where this was sorely lacking was to place the berries between layers of skyr and store in this way until the dark days of winter. Berries were also used to flavour whey and add to its nutritional value. In present times, there are more ways on offer for the storage of berries; they can be frozen, kept as preserves or boiled to produce cordial, juice or jelly. They are also delicious in sauces.

\section{Grains and seeds}

Leymus arenarius (L.) Hochst. has been commonly gathered as food along the southern coast of Iceland until the beginning of last century. It was used as a bread additive and has probably been gathered for human consumption since the Viking era [17].

\section{Lichens and algae}

Iceland is famous for using lichens, especially Iceland moss, Cetraria islandica (L). Arch., as regular food. We will deal with that separately below. The lichen Umbillicaria cylandrica (L.) Delise ex Duby is mentioned as famine food in the 18th century [18].
Algae have been of importance as a source for food in many maritime communities worldwide [33]. This is also the case with the Faroes and Iceland. Some species of seaweed especially Palmaria palmata (L.) Weber \& Mohr, Saccharina latissima (L.) C. E. Lane, C. Mayes, Druehl, \& G. W. Saunders, Ulva lactuca L., and Alaria esculenta (L.) Greville - were gathered along the shores on some Faroese islands. Seaweed was still gathered as food in the 1930s $[10,15,20]$.

In Iceland various species of seaweed such as dulse, Pamaria palmata, carrageen moss, Chondrus crispus Stackhouse, winged kelp (Alaria esculenta) and others were gathered. Mastocarpus stellatus (Stackhouse) Guiry, Laminaria digitata (Hudson) J. V. Lamouroux, and Laminaria hyperborea (Gunnerus) Foslie were gathered in times of famine. Especially P. palmata has long been used as food and a source of essential nutrition in times of famine. The oldest law texts deal with the right to collect dulse, as this was an important economic crop, collected, transported to inland farms and sold in exchange for other goods. Dulse was, and still is, widely distributed along the coast, although it is more abundant on the west and southwest coasts than elsewhere. A certain amount was gathered in the spring, but mostly the harvesting took place during spring-time at the end of June and again at the end of August. Dulse was mostly eaten with dried fish along with butter or some other kind of fat, or added to stews, porridges and blood sausages; later occasionally, with the addition of potatoes or turnips. It was used also to eke out rye flour in making bread. Nowadays dulse is gaining popularity in Iceland again, this time as health food. It is often used as a snack to chew on, consumed dry and in whole pieces, or as seasoning for soups and bread, as well as in pasta, fish and meat dishes [4,22].

Carrageen moss, Chondrus crispus, was in earlier times gathered in Iceland in much the same manner as $P$. palmata, and only came second in popularity to that seaweed. It is found on shores in the south and west. The species was mostly used in a kind of porridge or prepared into "fjörugrasahlaup" (Carrageen moss jelly) which was put into sour milk. Nowadays carrageen is mostly used in sashimi garnishes, as a soup ingredient and (less commonly) in salads or sold dried and ground as health seasoning [22,27].

\section{Spices and flavourings}

Ligusticum scoticum L. was mostly considered as a medicinal plant in the Faroes, but the aromatic young plant could have been used as a spice instead of parsley according to one source. Oxyria digyna L. was mixed in the gruel in order to make the dish sour $[15,20]$.

Pinguicula vulgaris L. was used instead of garlic in Iceland. Berries of Juniperus communis L. and the leaves of Thymus praecox Opiz have been used to flavour sour milk, Carum carvi L. was also used as a spice in Iceland [18].

\section{Beverages}

Dryas octopetala L. has been used as a substitute for tea in Iceland [18]. Ómar Gunnarsson, a native of Húsavík, is the only winemaker in Iceland, and the only one in the world to produce a wine made entirely from organic crowberries. This wine is made up of 80 per cent crowberries and 19 per cent rhubarb, the rest being wild blueberries and Icelandic herbs. This makes his wine highly unique due to its powerful antioxidant/anti-aging ingredients (Fig. 1). In the Faroes, a tea was brewed from the flowers of Thymus praecox Opiz. [20]. 


\section{Specific West Norse food plants}

There is of course a relationship between the use and availability of native plants [34]. Some taxa are known to have been used since the arrival of the Norse settlers, and are still specific for the Faroe Islands and Iceland. We will discuss two examples that have had particular cultural significance there.

\section{Angelica gardens}

Angelica has been used in Iceland, Greenland, in the Faroe Islands, and in northern Scandinavia. When the Vikings began trading expeditions in the 9th century, angelica was an important commodity. Growing angelica in primitive gardens has a long tradition in the Nordic countries, and was earlier common in the Faroes. Just before World War II, an observer wrote that angelica-gardens were disappearing [15,28]. However, well-kept angelica-gardens enclosed with stones have, until recently, been a source of pride for households in the Faroe Islands (Fig. 2). The angelica was harvested in the summer, especially for the Midsummer Festival and it could be gathered until the Festival of St. Olaf (29 July). Angelica stems were traditionally served together with thick, creamy sour milk, this being offered as a treat. It was also eaten fresh, picked either from the garden or in the wild on the mountainsides. Popular cookbooks still have recipes including this plant, for instance angelica mixed into rhubarb soup or as jelly. Since World War II it has been used mostly as an addition to rhubarb jam. Nowadays few people actually use it at home, but it is included in dishes served by catering companies offering Faroese local food on their menus. Rhubarb Rheum raponticum L., which was promoted as a food plant for home gardens in the first decade of the 20th century, has very much replaced the garden angelica $[15,29,31,35,36]$.

In Iceland, there are many swathes of angelica and special angelica gardens were known to exist in olden days. Right from the time of settlement angelica has been used for human consumption. Many toponyms still remind us of places for harvesting angelica. Grágás, the law book of the Icelandic Commonwealth (930-1262/ 1264), refers to penalties incurred for the theft of angelica, some as serious as being outlawed or fined heavily if the plant was stolen from someone else's garden. Angelica was an important way of eking out the household

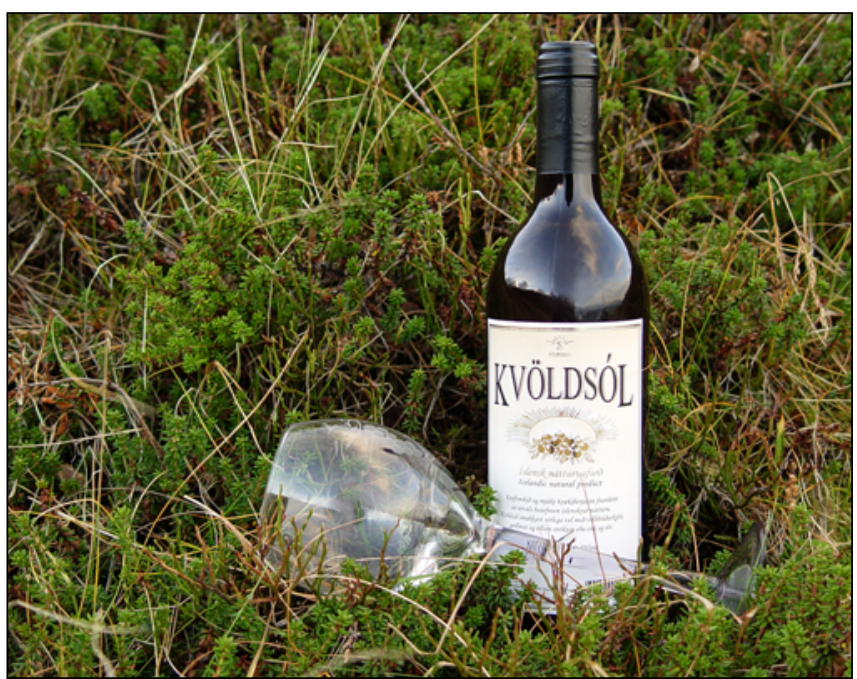

Fig. 1 Crowberry wine "Evening Sun" produced in Iceland (Photograph by Sigurður Ægisson). larder. All parts of the plant could be used - the seeds, leaves, stalks and roots - and were eaten fresh, fried (even grilled) or boiled (often in milk); or prepared in some other way. It depended on the region, however, how the plant was used and it appears to have been appreciated more in the eastern and southern parts of Iceland. Public knowledge of angelica and its cultivation has gradually disappeared during the past years, but interest in this plant has awakened once more with the health revolution of recent years and changing attitudes and awareness of people regarding food and nutrition supplements. We must not forget the Angelica Root Spirit, also exported to other countries. Angelica is also used in the kitchen as a fresh herb on meat or fish. The newest use for this versatile plant is as principal fodder for lambs to bring out a better spicy taste and fragrance in the meat on our table - right from the inside. During recent years, The University of Iceland has conducted studies into the garden angelica and rumours of its medicinal powers have gathered strength. It is now marketed as the Ginseng of the North [18,28,33,37].

\section{Iceland moss as a food plant}

Sources indicate that Iceland moss, Cetraria islandica (L.) Arch., has always played a major role in Icelandic culinary tradition possibly from the time of the earliest settlement. It is mentioned in the law collection Grágás. This lichen was in many ways a lifesaver for the people of those long ago days. The possibility of lichen gathering was, therefore, an advantage attached to some farms, seen as added benefit; especially if the lichen-covered areas were not too difficult to reach. It could be chopped up or just eaten whole. Those farms that were fortunate enough to own a piece of land with Iceland moss as a fringe benefit sent a group of people each year to collect enough supplies to last through the coming winter. The participants were mostly women and young people under the direction of one adult man. The group travelled on horseback and was equipped with tents, food and skin bags in which to put the gathered lichens. It was considered that two barrels of moss contained the nutritional equivalent of one barrel of flour. Many Icelandic idioms have their origins in these lichen-gathering trips. The longer excursions had for the most part been discontinued by the beginning of the 20th century $[18,21,38,39]$.

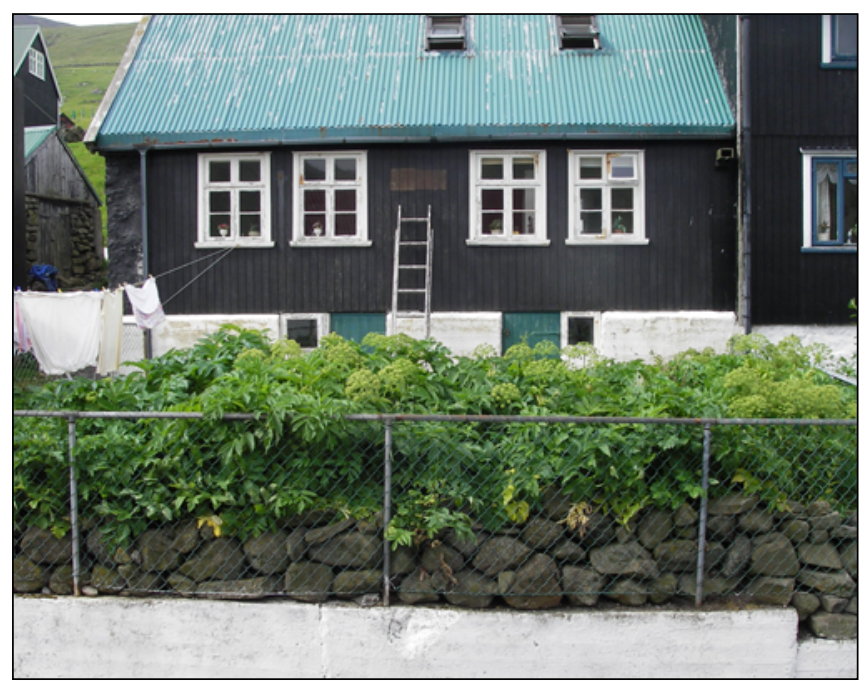

Fig. 2 Old angelica garden at Gjógv, Faroe Islands (Photograph by Ingvar Svanberg). 
Examples of the traditional type of recipe which included Iceland moss are:

(i) water gruel (the moss is steeped in water and cut up using a special curved knife; hot water is poured over the moss; flour or rice is added. The gruel is then boiled and served with milk),

(ii) moss milk (whole pieces of lichen are boiled in milk and the mixture eaten as a soup). Iceland moss is used to eke out the flour in bread and in the making of the Icelandic blood pudding, especially in times of great hardship,

(iii) Iceland moss tea (the lichen is boiled in water, then strained and the stock is used for drinking and was considered very wholesome). This beverage was also used for medicinal purposes, especially with regard to respiratory illnesses such as colds, pneumonia, asthma and tuberculosis. Some think it best to boil the lichens for only 5-15 minutes, as it is believed to become bitter if boiled for the whole hour; however, after 2-3 hours it takes on a sweet taste.

The use of Iceland moss has increased in the wake of the health revolution, with its desire to return to natural ways. In all the better bakeries in 21 st century Iceland, e.g. in Akureyri and Reykjavík, it is possible to buy bread with Iceland moss as one of its ingredients and this is thought to be extremely good (Fig. 3). Recent research has proved that the old belief in Iceland moss as a very useful product is not just a whim to be smiled at, and there is now a wide variety of health products available containing this ingredient [39].

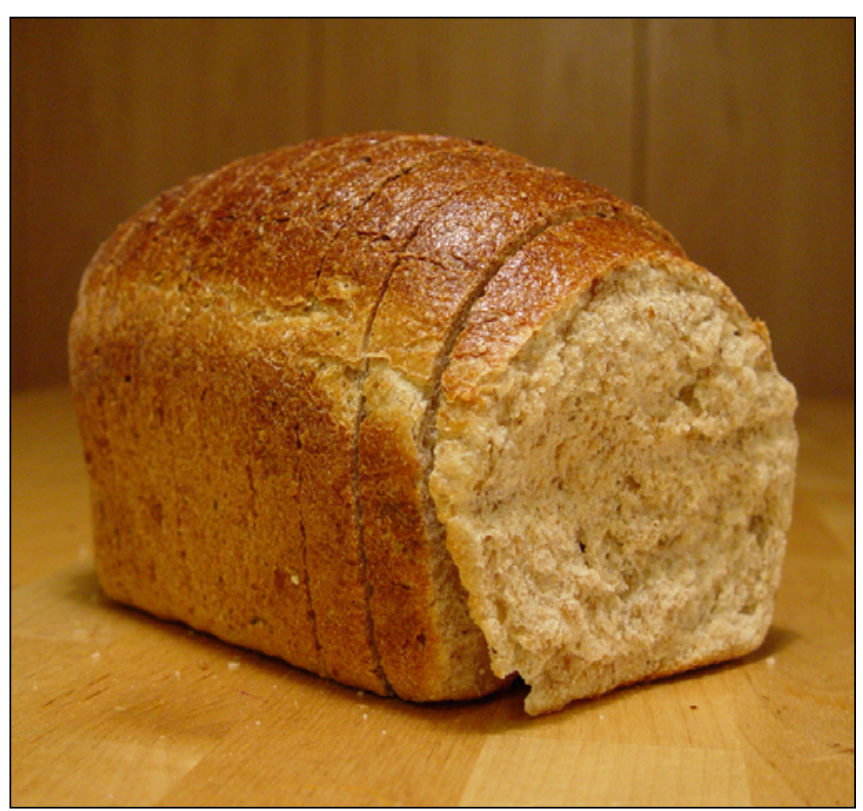

Fig. 3 Icelandic bread made with Cetraria islandica-flour (Photograph by Sigurður Ægisson).

During the Enlightenment the idea of using Iceland moss as a surrogate food was transferred from Iceland to Scandinavia and diffused into learned circles also elsewhere. In the late 18th and through the 19th century Iceland moss was promoted as a famine food in Norway, Finland, Sweden, Germany, Russia and even France. Inspired by the Icelandic traditional use, many botanists and economists, especially in time of famine and wants, published small booklets with recipes on lichen bread, lichen gruel and lichen pancakes, based on Cetraria islandica (L.) Arch. [40].

\section{Discussion}

Native, potentially edible plants in Iceland and the Faroese are few. Local plants play hardly any economic role as food in the contemporary Faroe Islands, although there is a degree of interest in reviving the use of garden angelica, and some people still prepare food with angelica as an ingredient. Rumex acetosa L. is sometimes used in homemade food.

Some plants are still gathered and made into food products by small companies, especially in Iceland. There is also an increasing interest in the use of local plants [41,42]. Two taxa have been exploited as food exclusively in Iceland: Cetraria islandica (L.) Arch. and Elymus arenarius L. Although propaganda efforts by authorities and enlightened persons in the 18th and 19th century in Scandinavia and other countries tried to promote Iceland moss as a surrogate food in times of food crises, it never became accepted by the peasantry. However, the Icelanders have used it since the early settlement days and continue to do still today. Wild grasses have been harvested for food elsewhere (e.g. [43]), but the use of lyme-grass seems to be restricted to Iceland.

\section{References}

1. Svanberg I, Łuczaj Ł, Pardo-de-Santayana M, Pieroni A. History and current trends of ethnobiological research in Europe. In: Anderson EN, Pearsall DM, Hunn ES, Turner NJ, editors. Ethnobiology. Hoboken NJ: Wiley-Blackwell; 2011. p. 191-214.

2. Łuczaj Ł, Szymański WM. Wild vascular plants gathered for consumption in the Polish countryside: a review. J Ethnobiol Ethnomed. 2007;3(1):17. http://dx.doi.org/10.1186/1746-4269-3-17

3. Guðjónsson SV. Folkekost og sundhedsforhold i gamle dage: belyst igennem den oldnordiske litteratur. København: Arnold Busck; 1941.

4. Jonsson G. Changes in food consumption in Iceland, 1770-1940. Scand Econ Hist Rev. 1998;46(1):24-41. http://dx.doi.org/10.1080/03585522.1 998.10414677

5. Zutter C. Wood and plant-use in 17th-19th century Iceland: archaeobotanical analysis of Reykholt, Western Iceland. Environmental Archaeology. 2000;5:73-82.

6. Tómasson T. Iceland: country report to the FAO international conference on plant genetic resources. Leipzig: FAO; 1996.

7. Guttesen R. Food production, climate and population in the Faeroe Islands 1584-1652. Geogr Tidsskr. 2004;104:35-46.

8. Guttesen R. Plant production on a Faeroese farm 1813-1892, related to climatic fluctuations. Geogr Tidsskr. 2001;101:67-76.

9. Rasmussen H. Die Nahrungsforschung auf den Färöer. Ethnol Eur. 1971;5:49-52.

10. Joensen JP. Fiskafólk. Ein lýsing av føroyska húshaldinum í slupptíðini. Tórshavn: Føroya Sparikassi; 1982.

11. Kristinsson H. A guide to the flowering plants and ferns of Iceland. Reykjavik: Örn og Örlygur; 2010.

12. Jóhansen J. Studies in the vegetational history of the Faroe and Shetland Islands. Tórshavn: Føroya Fróđskaparfelag; 1985. (Annales Societatis Scientiarum Færoensis; vol 11).

13. Harshberger JW. The gardens of the Faeroes, Iceland, and Greenland. Geogr Rev. 1924;14(3):404. http://dx.doi.org/10.2307/208421

14. Jóhansen J. Medicinal and other useful plants in the Faroe Islands before ad 1800. Bot J Scotl. 1994;46(4):611-616. http://dx.doi. org/10.1080/13594869409441771

15. Svanberg I. The use of wild plants in the Faroe Islands 1590-1990: a contribution to Scandinavian ethnobotany. Svenska Linnésällskapets Årsskrift. 1998;1996-1997:81-130. 
16. Svanberg I. Plant knowledge as indicator of historical cultural contacts: tanning in the Atlantic fringe. In: Pieroni A, Vandebroek I, editors. Traveling cultures and plants: the ethnobiology and ethnopharmacy of migrations. Oxford: Berghahn Books; 2007. p. 227-244.

17. Guðmundsson G. Gathering and processing of lyme-grass (Elymus arenarius L.) in Iceland: an ethnohistorical account. Veg Hist Archaeobot. 1996;5(1-2):13-23. http://dx.doi.org/10.1007/BF00189431

18. Olafsen E. Vice-Lavmand Eggert Olafsens og Land-Physici Biarne Povelsen Reise igiennem Island, franstaltet af Videnskabernes Sælskab i Kiøbenhavn. Sorø: Videnskabernes Sælskab; 1772. (vol 1-2).

19. Svabo JC. Indberetninger fra en Rejse i Færøe 1782 og 1783. København: Selskabet til Udgivelse af færøske Kildeskrifter og Studier; 1959.

20. Rasmussen R. Gróðranýtsla fyrr í tíðini: til matna, til lækningar, til litagerðar og til ídnaðar. Tórshavn: Landnám; 1946.

21. Halldórsson B. Grasnytjar. København: August Friedrich Stein; 1783.

22. Kristjánsson L. Îslenzkir sjávarhættir. Reykjavík: Menningarsjóður; 1980. (vol 1-5).

23. Høeg OA. Planter og tradisjon Floraen i levende tale og tradisjon i Norge 1925-1973. Oslo: Universitetsforlaget; 1974.

24. Turner NJ, Łuczaj ŁJ, Migliorini P, Pieroni A, Dreon AL, Sacchetti LE, et al. Edible and tended wild plants, traditional ecological knowledge and agroecology. Cr Rev Plant Sci. 2011;30(1-2):198-225. http://dx.doi.org/ 10.1080/07352689.2011.554492

25. Holmboe J. Mura (Potentilla anserina L.) og dens bruk som matnyttig plante i ældre og nyere tid. Svensk Botanisk Tidskrift. 1928;22:160-168.

26. Svanberg I. Field horsetail (Equisetum arvensis) as food. Fróðskaparrit. 1997;45:45-55.

27. Mohr N. Forsøg til en islandsk naturhistorie, med adskillige oekonomiske samt andre anmærkninger. København: Christian Friderik Holm; 1786.

28. Svanberg I. Kvannen (Angelica archangelica) på Färöarna och Island. Gardar: Årsbok för Samfundet Sverige-Island i Lund-Malmö och Samfundet Sverige-Färöarna. 2008;38:22-28.

29. Skaale Ö, Johannesen M. Matur og matgerð. 5th ed. Tórshavn: Bókaforlagið Grønalið; 1990.

30. Nordal A. Über einige norwegische volksmedizinische Skorbut-Pflanzen, und ihren Vitamin-C-Gehalt. Nytt Mag Naturv. 1939;79:193-231.
31. Debes LJ. Færoæ et Færoa Reserata, det er: Færøernis oc færøeske Inbyggeris beskrifvelse. København: Matthias Jørgensøn; 1673.

32. Bjarnason AH. Íslensk flóra með litmyndum. Reykjavík: Iðunn; 1983.

33. Aaronson S. Algae. In: Kiple KF, Ornelas KC, editors. The Cambridge world history of food. Cambridge: Cambridge University Press; 2000. p. 231-249.

34. Albuquerque UP, Hanazaki N. Five problems in current ethnobotanical research - and some suggestions for strengthening them. Hum Ecol. 2009;37(5):653-661. http://dx.doi.org/10.1007/s10745-009-9259-9

35. Joensen HD. Um hvonnina í Føroyum, serliga um nýtsluna til matna og um hvannsárið. Varðin. 1951;29:129-154.

36. Simonsen M. Konurák. Tórshavn: Mentunargrunnur Studentafelagsins; 1989.

37. Fosså O. Angelica: from Norwegian montains to the English trifle. In: Hosking R, editor. Wild food: proceedings of the Oxford Symposium on Food and Cookery, 2004. Totnes: Prospect books; 2006. p. 131-142.

38. Mehler M. From self-sufficiency to external supply and famine: foodstuffs, their preparation and storage in Iceland. In: Klápste J, Sommer P, editors. Processing, storage, distribution of food food in the Medieval rural environment. Turnhout: Brepols; 2011. p. 173-186.

39. Gísladóttir H. Substitutes for corn in Iceland. In: Lysaght P, editor. Food from nature. Uppsala: The Royal Gustavus Adolphus Academy for Swedish Folk Culture; 2000. p. 148-154. (Acta Academiae Regiae Gustavi Adolphi LXXI; ).

40. Nelson MC, Svanberg I. Lichens as food: historical perspectives on food propaganda. Svenska Linnésällskapets Årsskrift. 1987;1986-1987:7-51.

41. Whitney CW. A survey of wild collection and cultivation of indigenous species in Iceland and the Faroe Islands [Master thesis]. Witzenhausen: University of Kassel; 2011.

42. Whitney CW, Gebauer J, Anderson M. A survey of wild collection and cultivation of indigenous species in Iceland. Hum Ecol. 2012;40(5):781-787. http://dx.doi.org/10.1007/s10745-012-9517-0

43. Łuczaj ŁJ, Dumanowski J, Köhler P, Mueller-Bieniek A. The use and economic value of manna grass (Glyceria) in Poland from the middle ages to the twentieth century. Hum Ecol. 2012;40(5):721-733. http://dx.doi. org/10.1007/s10745-012-9513-4 